\title{
Glossy
}

\section{Polskie poranne pieśni miłosne XVI-XVII wieku w świetle typologii podgatunków chansons de femme}

Grażyna Urban-Godziek
Artykuł powstałw ramach realizacji projektu badawczego "Od paraklausithyronu do serenady" $\mathrm{nr}$ 2012/07/B/HS2/01297 finansowanego ze środków Narodowego Centrum Nauki.

TEKSTY DRUGIE 2019, NR 2, S. 222-240

DOI: 10.18318/td.2019.2.17 | ORCID 0000-0003-4140-9403

\section{Wstęp}

Celem prezentowanych tu badań była identyfikacja wzorca gatunkowego grupy polskich renesansowych i barokowych miłosnych pieśni porannych, z wyłączeniem jednak cykli hejnałowych, którym poświęcę osobne studium.

Przystępując do tej pracy, sądziłam, że - analogiczne do serenady, której wyznacznik gatunkowy opiera się wyłącznie na określonej sytuacji lirycznej (amant śpiewający nocną porą pod oknem ukochanej) - poszukiwanie wspólnego wzorca genologicznego opierać się winno na łączącym je temacie: obraz świtu, blasku zorzy porannej, której pojawienie się ma określone konsekwencje dla kochanków (odmienne w zależności od wariantu). Motyw ten obecny chyba we wszystkich literaturach ${ }^{1}$, w Europie znalazł najbardziej sformalizowaną postać

1 Monografię motywu wraz z przykładami z poezji całego świata stanowi Eos: An Enquiry Into the Theme of Lovers'Meetings and Partings at Dawn in Poetry, ed. by A.T. Hatto, Mouton \& Co., Hague 1965.

\section{Grażyna Urban-}

-Godziek - dr hab., kierownik Pracowni Literatury Renesansu UJ, polonistka i neolatynistka. Wybrane publikacje: Elegia Renesansowa. Przemiany gatunku w Polsce i w Europie (2005); Renaissance and Humanism from the Central-EastEuropean Point of View. Methodological Approaches, red. (2014), art.: Florencki złoty wiek w propagandzie medycejskiej... (2016). Kontakt: grazyna. urban-godziek@ uj.edu.pl 
w prowansalskiej albie (nagłe pojawienie się zorzy porannej [alba] niweczy nocne rozkosze potajemnych kochanków, witają więc ją z niechęcią i trwogą). Stworzona przez trubadurów, a zatem przynależna do gatunków dworskich, uczonych, już w czasach swego rozkwitu poddana została namysłowi krytycznoliterackiemu. Wydawało się więc, że definiowana w traktatach poetyckich już od końca XIII wieku alba, mająca też (w przeciwieństwie do serenady) bardzo bogatą literaturę przedmiotu, będzie odpowiednim punktem startowym dla opisu polskich pieśni porannych, a następnie również wieczornych często bowiem łączą się one, tworząc minicykle pieśniowe ilustrujące swoistą „adorację nieustającą" od zmierzchu do świtu.

Zaznajomienie się ze współczesnymi badaniami nad średniowieczną liryką romańską skłoniło mnie jednak do sformułowania wniosków, że omawiane tu teksty,jak również ogromna część innych polskich utworów określanych dawniej jako liryka mieszczańsko-ludowa, są pochodną gatunków należących do romańskiej liryki popularnej.

Tradycyjna XIX-wieczna genologia zwykła dzielić literaturę, a w tym i najstarsze miłosne pieśni romańskie i germańskie, na tę przynależną do poezji uczonej, dworskiej, arystokratycznej oraz popularną, ludową. W omawianym przypadku ta pierwsza to twórczość trubadurów i truwerów, le grand chant courtois wraz ze swoim systemem miłości dwornej fin'amor, amour courtois; ta druga - ludowa, reprezentowana przez chansons de femme - wywodzić się miała z tradycji pierwotnej, pogańskiej, gallo-rzymskiej lub celtyckiej, łączona była z obrzędami ku czci Wenery i majowymi kultami wiosny. W ostatniej ćwierci XX wieku porzucono ten sztywny podział oraz wartościowanie obu nurtów (np. w myśl idei romantycznych literaturę ludową uznawano za rodzimą, wyrażającą szczere uczucia, bardziej moralną niż ta uczona, arystokratyczna). Dziś wiemy, że zarówno geneza, jak i funkcjonowanie społeczne obu nurtów stanowią znacznie bardziej skomplikowane zagadnienie. Eliminuje się też, ferowane chętnie przez dawnych badaczy, a niepotwierdzone nowymi znaleziskami, hipotezy zaginionych ogniw, jak rzekoma rycerska pieśń wartownicza jako podstawa alby czy istnienie miłosnej liryki celtyckiej. Oparty na rosnącym zbiorze wydobytych z manuskryptów i wydawanych obecnie tekstów, rozwój badań nad dworską poezją hispano-arabską i ludową mozarabską w językach romańskich, z której wywodzi się popularna liryka iberyjska, każą raczej tu upatrywać owego brakującego ogniwa.

Intrygujące wydają się jednak nie tylko korzenie romańskiej liryki popularnej, ale i jej niezwykła żywotność, skoro w tych samych gatunkach tworzyli swoje pieśni poeci i śpiewacy w całej nowożytnej Europie, a w tym, jakże 
chętnie, zarówno uczeni, jak i wywodzący się z niższych warstw, władający polskim lub ruskimi dialektami mieszkańcy Rzeczypospolitej. Ogromną bowiem większość polskich i ruskich pieśni miłosnych zachowanych w drukowanych anonimowo śpiewnikach ${ }^{2}$, jak również pisanych przez najwybitniejszych poetów renesansu i baroku można by łatwo sklasyfikować, używając typologii stworzonej dla opisu średniowiecznej popularnej liryki francuskiej. Kilka przykładów prezentuję poniżej. Tę może nazbyt śmiałą dla polskiego czytelnika tezę poprzeć należałoby charakterystyką owego nurtu.

Podstawowym rodzajem lirycznym tzw. nurtu popularnego poezji romańskiej jest pieśń kobieca - chanson de femme, czy w wersji na południe od Pirenejów - canción de mujer ${ }^{3}$. Poezja dworska, jak ta tworzona przez trubadurów, choć w centrum wyrafinowanej adoracji stawiała damę, pisana była z perspektywy męskiej i eksponowała uczucia mężczyzny. Natomiast pierwotna liryka romańska przemawia głosem kobiety ${ }^{4}$. W obrębie chansons de femme mieszczą się rozmaite gatunki, których wspólną cechą jest monolog liryczny o charakterze lamentacyjnym, włożony w usta kobiety. Według opisu prawodawcy francuskich badań nad liryką średniowieczną, Alfreda Jeanroya, w chanson de femme „Kobieta zwraca się do przyjaciółki, do matki lub, niezwykle rzadko, do swego amanta, obecnego lub nie"5. W pieśni francuskiej osoba adresata jest zazwyczaj milcząca. Natomiast w poezji portugalskiej,jak również niemieckiej, wiersz niekiedy przybiera postać dialogu.

Najbardziej podstawowa forma pieśni kobiet to gatunek chanson d'ami (lub de jeune fille) - pieśń dziewczyny tęskniącej za nieobecnym kochankiem. W każdej z tradycji, które musimy tu wziąć pod uwagę, istnieje jej odpowiednik. W poezji hispano-arabskiej była to kharja (hiszp. jarcha) - romański refren czy pointa kończąca arabski lub hebrajski wiersz w gatunku

2 Najobfitszy zbiór pieśni popularnych: Polska liryka mieszczańska. Pieśni - tańce - padwany, opr. K. Badecki, Nakładem Towarzystwa Naukowego, Lwów 1936.

3 Odwołuję się tu głównie do opatrzonej antologią monografii: P. Bec La lirique française au Moyen Âge (XII -XIII' siècles). Contribution à une typologie des genres poétiques médiévaux. Études et textes, vol. 1: Études, vol. 2: Texts, Picard, Paris 1977.

4 Jest to zresztą charakterystyczne dla wielu archaicznych literatur, w czym niektórzy badacze domyślają się echa pierwotnego matriarchatu. Zob. zestawienie przykładów i ich interpretację P. Dronke Medieval Latin and the rise of European love-lyric, vol. I, Clarendon Press, Oxford 1999, S. 1-46.

5 A. Jeanroy Les origines de la poésie lyrique en France au Moyen-Âge. Études de littérature française et comparée suivies de textes inédits, Libraire Hachette, Paris 1889, s. 158. 
muwaszszah) ${ }^{6}$. Jego pochodną wydaje się galicyjsko-portugalska cantiga de amigo. Francuskie chansons d'ami wywodzą się zapewne z tego źródła, choć istniała i frankońska pieśń zwana winileodae $e^{7}$ Znane dziś świadectwa rękopiśmienne są późne, tych najstarszych jest niewiele, każą jednak domyślać się tradycji bardzo archaicznej. Należy przy tym wystrzegać się traktowania tej twórczości jako „ludowej” w przeciwieństwie do dworskiej, skoro np. najstarsze znane galicyjsko-portugalskie cantigas de amigo - pełne lirycznej prostoty skargi zawiedzionych w miłości dziewcząt - powstały pod piórem portugalskiego króla-trubadura, niezwykle światłego reformatora i budowniczego kraju, Dionizego I (1261-1325). Powtórzmy też za piszącym w tym kontekście Peterem Dronke, który wykazuje istnienie poezji typu courtois w różnych literaturach i środowiskach, „Popular poetry [...] is composed not by people but for it".

Ten dawny typ liryki romańskiej został jednak przytłumiony i wyparty z głównego nurtu przez formy poezji dworskiej wypracowane w niezwykle ekspansywnej kulturze oksytańskiej (prowansalskiej). Kulturę tę tworzyło środowisko wysoce piśmienne, kształcone w szkołach łacińskich, w charakteryzującej się rozwojem badań nad tradycją klasyczną epoce prerenesansu XII-wiecznego, zwanego też aetas Ovidiana. Komponowana przez trubadurów poezja meliczna powstawała w języku oksytańskim, podążając i za średniowieczną tradycją łacińską, i za dworskimi nurtami andaluzyjskimi ${ }^{9}$, jak również czerpiąc z rodzimej tradycji pieśniowej. Język trubadurów na trzy wieki stanie się językiem dworów i ludzi kultury, a wypracowany przez nich styl courtois, sformalizowany system miłosny i kod zachowania, legną u podstaw europejskiej etykiety dworskiej i na długie wieki wyznaczą wzorzec postępowania dżentelmena.

6 O odkryciu gatunku khari doniósł pierwszy S.M. Stern w: Les vers finaux en espagnol dans les muwaššahs hispano-hebraïques: Une contribution à l'histoire du et à l'étude du muwaššahs vieux dialecte espagnol'mozarab', "Al-Andalus" 1948 No. 13. Zob. też dysertacja doktorska: J. Hawking The dawn - a study of the traditional love lyric of Medieval Spain and Portugal, University of London, London 1979 (dostępna on-line) i zwłaszcza cykl trzech artykułów: P. Le Gentil La strophe zadjalesque, les khardjas et le problème des origines du lyrisme roman, "Romania” 1963 No. 84 , S. 1-27, 209-250, 409-411.

7 P. Dronke Medieval Latin..., s. 275-277.

8 Tamże, s. 1.

9 Zob. np. R. Boase Arab influence on European love-poetry, w: The Legacy of Muslim Spain, vol. 2, ed. by S. Khadra Jayyusi, Brill, Leiden 1992, s. 465-466; J.T. Monroe Zajal and muwashsha a: Hispanoarabic poetry and the Romance tradition, w: tamże, s. 398-419. 
Trubadurzy część z popularnych gatunków i motywów zaadaptowali, łącząc je z dworną canso. Z kolei wyrafinowana, kunsztowna liryka dworska stała się wzorcem dla twórców spoza tego środowiska. W takiej wymianie kulturowej silniejsza okazała się pieśń rycerska i w efekcie nurt francuskiej liryki typu chanson de femme został przytłumiony i wyparty przez chanson trobarique. Ten zdetronizowała w XVI wieku kolejna wielka maniera stylistyczna, również tłumiąca ekspansję i rozwój innych tradycji, czyli petrarkizm, który szybko zawładnął również poezją popularną.

Chansons de femme zostały więc wchłonięte przez gatunki dworskie, zaś te popularne, tworzone przez poetów spoza elit, przybrały szaty dworskie. Echa pierwotnych wersji przetrwały jednak w folklorze, zwłaszcza w archaicznych formach refrenów pieśniowych, które badał już wspomniany Jeanroy ${ }^{10}$, choć także w gatunkach bardziej sformalizowanych (czyli o wyznacznikach nie tylko tematycznych, ale i strukturalno-formalnych), jak rondets de carole, ballettes, virelis, pastorelle, a później motetach, w których z kolei występują elementy stylu dwornego, zarówno w zakresie treści, jak i formy"1. Przez te gatunki pieśniowe i taneczne (czyli oddziałujące poprzez medium muzyczne) rozpowszechniły się w Europie nowożytnej na czele z włoską, z czasem nabierając też rysów poezji petrarkistowskiej. Takie rozmaite ich postacie możemy znaleźć w XVII-wiecznych zbiorach pieśni z terenów Rzeczypospolitej.

Wróćmy jednak do chanson d'ami. Jest to zwykle monolog liryczny wyrażający tęsknotę za ukochanym - potencjalnym, nieobecnym lub niewiernym. Wiele mówi się tu też o przyczynach uniemożliwiających spotkania - winni są zazwyczaj rodzice, a zwłaszcza matka. Czasem opiewane bywa uczucie wzajemne i szczęśliwe. Wokół podstawowego typu chanson d'ami narosły podgatunki - rozmaite warianty tematyczne, odpowiadające różnym okolicznościom i sytuacjom uczuciowym. Dwa główne to chansons de délaissée i chansons de départie - oba warianty często w scenerii wschodzącego słońca.

Chanson de départie (pieśń na odjezdnym) lub d'adieux (pieśń pożegnania) wyraża żal spowodowany odjazdem, następnie nieobecnością kochanka. Zwykle brak przyczyny rozstania, czasem dowiadujemy się, że kochanek jest rycerzem lub żołnierzem, który podąża za dworem władcy lub za armią, by się wyróżnić (w pieśniach portugalskich zmierza do Grenady, by zabić wielu Maurów). We Francji, gdzie temat wszedł do rejestru courtois - połączony

10 A. Jeanroy Les origines..., S. 180-184.

11 P. Bec La lirique..., S. 59. (Pisownia nazw gatunkowych wg tego źródła). 
$\mathrm{z}$ canso odnalazł się $\mathrm{w}$ ramach chansons de croisade. Tu jednak role bohaterów są odwrócone, bo to odjeżdżający rycerz boleje i tęskni za swą damą ${ }^{12}$.

Chanson de délaissée (pieśni porzuconej) - lament opuszczonej dziewczyny żalącej się na niewiernego kochanka. Szereg wariantów, jak la fille enceinte abandonnée (porzucona dziewczyna w ciąży) czy la délaissée qui assiste aux noces de sa rivale (porzucona, która bierze udział w ślubie rywalki). W poezji portugalskiej istnieją teksty osnute wokół tematu wykorzystanej i porzuconej o świcie. Temat de délaissée niezwykle żywotny, obecny zarówno w twórczości uczonej, jak i popularnej, zwłaszcza w średniowiecznej poezji portugalskiej i włoskiej (świadectwa z XIII i XIV wieku), we francuskiej mamy poświadczenia tekstowe dopiero z XV wieku ${ }^{13}$. Na koniec wspomnieć trzeba, że wszystkie średniowieczne wersje chanson d'ami to pieśni dziewczyny o miłości do kochanka, dopiero wraz z nasilającą się chrześcijańską presją obyczajową zaczynają pojawiać się wersje małżeńskie.

Kolejnym znaczącym gatunkiem lirycznym należącym do działu chansons de femme jest chanson de malmariée (pieśń źle wydanej za mąż). To typ bardzo obficie reprezentowany i mający wiele odmian poważnych, jak też parodystycznych $^{14}$. Jego wyróżnikiem formalnym jest postać narratora-poety, który we wstępie zapowiada skargę kobiety. Bywa on wyłącznie słuchaczem bądź też uczestniczy w dialogu z kobietą, która żali się kochankowi lub przyjaciółce. Niekiedy stara się pomóc w pogodzeniu małżonków czy pocieszyć płaczącą ${ }^{15}$. Chanson de malmariée snuta jest wokół tematu nieszczęśliwej kobiety pozostawionej w domu, która płacze nad swoim losem lub lamentuje nad mężem, którym z różnych przyczyn pogardza (głównie dlatego, że została wydana za mąż wbrew woli). Nieodzowny jest tu pocieszyciel. W średniowiecznych wersjach mamy dwa warianty: malmariée ma już kochanka, z którym radośnie zdradza męża, albo jak najszybciej pragnie go zdobyć. W obu przypadkach wiersz (o zabarwieniu dramatycznym, patetycznym, sentymentalnym lub ironicznym czy żartobliwym) opiera się na kontraście męża i kochanka (również tego potencjalnego) - pierwszy jest odpychający, zazdrosny, stary, niegodziwy, gwałtowny, brzydki, skąpy, impotent, natomiast kochanek młody,

12 Tamże, s. 67, przyp. 30. Bec podaje wiele przekładów z poezji truwerów, jak również z poezji sycylijskiej (XIII wiek).

P. Bec La lirique..., s. 65.

14 Tamże, s. 69-9o.

15 P. Aebischer Une chanson de "mal mariée» dans un manuscrit du XVe siècle, "Romania" 1928, S. 492-503. 
piękny, dworny, ujmujący, gorący w miłości etc. Zdarza się też i trzecia opcja: żona dzieli swój czas między męża i kochanka - ale to już blisko ludowych obscenicznych wersji typu femme légère. Jest to więc ten sam przypadek, co chanson d'ami, tylko zamiast młodej dziewczyny mamy mężatkę.

Począwszy od XV wieku pojawiają się kolejne warianty: malmariée virtuelle - młoda dziewczyna wbrew woli przyrzeczona nienawidzonemu mężczyźnie; chanson de nonne - młoda mniszka zamknięta przez rodziców w klasztorze, lamentuje, przyzywa ze wszystkich sił ukochanego, by ją wyswobodził (przykłady już od XIII wieku); misère en ménage - wariant bez kochanka, poważny i realistyczny: kobieta płacze nad swoimi losem, problemami związanymi z prowadzeniem domu i wychowaniem dzieci, utratą młodości i niegdysiejszej dziewczęcej beztroski, nad kłopotami materialnymi, złym traktowaniem przez męża, który pije, gra i zdradza. Nie jest gburem, starcem czy zazdrośnikiem, jak w wersjach tradycyjnych, co służyło usprawiedliwieniu posiadania kochanka, lecz realną przyczyną niepokoju' ${ }^{16}$.

\section{Polskie pieśni poranne}

O ile pieśni wieczornych i serenad znajdziemy zwłaszcza w XVII-wiecznej poezji polskiej całkiem sporo, o tyle pieśni porannych raczej niewiele. Spójrzmy na poniższe przykłady, które prócz tematu świtu łączy odległy, ale jednak dostrzegalny wzorzec romańskich chansons de femme.

\section{Skargi porzuconych}

\section{Chanson de malmariée, heroida}

\section{Jan Kochanowski}

Ponieważ polską lirykę nowożytną ukształtowaną według wzorów klasycznych, ale też i rozmaitych nurtów europejskich rozpoczyna dzieło Jana Kochanowskiego (1530-1584), od niego zacznijmy tę prezentację. Zbiory pieśni poety wydane zostały pośmiertnie. Pieśni ksiag dwoje (1586), zapewne w układzie autora, zawierają horacjańskie ody (wśród nich elegijny cykl miłosny). Natomiast tzw. Pieśni z Fragmentów ukazały się w przygotowanym przez Jana

16 Ten ostatni temat nader często pojawia się w polskich śpiewnikach z XVII wieku, niekiedy w szacie wiejskiej rubaszności. Można to tłumaczyć uniwersalnością doświadczenia - niemniej rzadko bita przez pijanego męża żona i matka ujmuje swoją skargę w liryczne wyznanie o regularnej budowie stroficznej i metrycznej. Żeby doświadczenie egzystencjalne przybrało formę artystyczną, musi istnieć forma, wzorzec. Ponadto wiersze te pisane były przez mężczyzn. 
Januszowskiego tomie Fragmenta albo pozostałe pisma (1590). Wśród nich znalazły się pieśni oparte na wzorcach romańskich. Ciekawy przykład stanowi tu Pieśń VIII będącą adaptacją Heroidy VIII Hermione Oresti, Owidiusza, lecz na modłę romańską. W oryginale bohaterką jest Hermiona, córka Menelaosa, który przyobiecał jej rękę synowi Achillesa, Pyrrusowi. Nie wiedząc o tym, dziadek dziewczyny, Tyndareos, zaręczył ją ze stryjecznym bratem Orestesem, którego pokochała. O swoje prawa upomniał się jednak Pyrrus, porwał i uwięził dziewczynę. Owidiusz przytacza jej list - przyzywa w nim Orestesa, skarżąc się na los i znienawidzonego męża, który siłą ją zniewolił.

Przykład Pieśni VIII z Fragmentów pokazuje wypracowaną przez Kochanowskiego technikę parafrazowania literatury klasycznej w języku polskim. Składa się na nią: uniwersalizacja sytuacji lirycznej (rezygnacja z realiów i nazw antycznych), jak najpełniejsze wtopienie tekstu łacińskiego w polski język i tradycję literacką, m.in. za pomocą odwołań do rodzimych pieśni czy zwrotów przysłowiowych, oraz nadanie tekstowi formy melicznej. Prócz imion bohaterów i realiów pierwowzoru Kochanowski odrzuca również formę epistolograficzną heroidy. Zamiast listu mamy skargę podsłuchaną i zrelacjonowaną przez mimowolnego świadka-poetę, przy czym realia odbiegają od antycznych: rzecz dzieje się nad Wisłą, a dama siedzi w wysokiej wieży, jak bohaterka średniowiecznych hiszpańskich romanc. Ten zabieg nadaje wierszowi formę znaną z gatunku chanson de malmariée ${ }^{17}$.

Kiedy się rane zapalają zorza,

A dzień z wielkiego występuje morza, -

Przyszedłem na brzeg, kędy Wisła bieży,

A tam siedziała na wysokiej wieży,

Podjąwszy rękę, smutna białagłowa,

I pocznie z płaczem narzekać w te słowa: ${ }^{18}(1-6)$

W komentarzu do pieśni Elwira Buszewicz ${ }^{19}$ przywołuje przypadek, który należałoby uznać za odwrotny - łacińską parafrazę anonimowej pieśni Ich

17 Na pokrewieństwo z tym gatunkiem zwracał uwagę już St. Dobrzycki Pieśni Kochanowskiego, Kraków 1906, s. 9, oraz M. Brahmer Petrarkizm w poezji polskiejXVI wieku, Kasa im. Mianowskiego, Kraków 1927, s. 71-75.

J. Kochanowski Dzieła polskie, red. J. Krzyżanowski, t. 3, PIW, Warszawa 1955, s. 21-22. dia o Janie Kochanowskim, red. E. Lasocińska, W. Pawlak, Wydawnictwo IBL PAN, Warszawa 2015, s. 136. Stąd pochodzą poniżej cytowane fragmenty. 
stund an einem Morgen dokonaną przez Heinricha Bebla (1472-1518). Bebel używa bowiem frazeologii elegijnej dla oddania skargi dziewczyny, którą porzuca niewierny kochanek po roku spędzonym w jej ramionach i na jej wikcie - czyli klasycyzuje popularną pieśń niemiecką. W oryginale zaznaczona jest tylko pora dnia (Morgen), humanista poprzedza jednak dialog kochanków opisem świtu zaczerpniętym z mitologii:

Tempore quo coniunx Tithonum mane reliquit

Occulto steteram conditus ipse loco:

Hic illam audivi miseranda voce querelam,

Qua flet amatoris pulchra puella abitum. (1-4)

[Rankiem, gdy Titonosa żona opuściła,

Cicho w tajnej kryjówce niewidoczny stałem

I gdy się na odejście miłego żaliła

Z płaczem piękna dziewczyna, smutną pieśń słyszałem].

(przeł.E. Buszewicz)

Poeci rzymscy, a za nimi renesansowi, do opisu wschodu jutrzenki wykorzystywali różne wersje mitu o Eos-Aurorze. Bebel przywołuje jej związek z królem Etiopii Titonosem. Wyprosiła dla niego nieśmiertelność, zapominając o wiecznej młodości - co wieczór jednak powraca do starca, by o świcie znów wstąpić na nieboskłon. Tak zaczyna najsłynniejszy, inspirujący wiele nowożytnych alb, opis świtu Owidiusz w elegii z Amores I 13:

Iam super oceanum venit a seniore marito

flava pruinoso quae vehit axe diem.

'Quo properas, Aurora? mane ${ }^{20}[\ldots](1-3)$

[Właśnie nad ocean od swego starego męża wraca płowowłosa prowadząc na oszronionym wozie dzień. Gdzie się spieszysz, Auroro? Zostań!]

Podobnie Wergiliusz w Eneidzie IV 584-585 (powtórzone w IX 459-460): „Et iam prima nouo spargebat lumine terras / Tithoni croceum linquens Aurora cubile” [„A spryskała już krainy nowym / Światłem Jutrzenka wczesna,

20 Cytaty z poezji klasycznej podaję za stroną http://www.thelatinlibrary.com. Jeśli nie zaznaczono inaczej, przekład mój [G.U.-G.]. 
wynurzona / Z szafranowego łoża Tytona"21]. Owidiusz w Heroidzie VIII nie wspomina o jutrzence, lecz o tytanie Heliosie-słońcu, które wschodzi na nieboskłon, przynosząc ukojenie po bezsennej nocy pełnej łez i rozpamiętywania niedoli: „cum tamen altus equis Titan radiantibus instant, / perfruor infelix liberiore malo” (113-114) [„Kiedy Tytan wznosi się wysoko na swym promiennym zaprzęgu, lżej mi nieszczęsnej na duszy"22] i opis ten znajduje się na końcu elegijnego listu. Adaptując łacińską kwerelę $e^{23}$ Hermiony w języku popularnym (volgare), Kochanowski nadaje jej więc formę melicznej średniowiecznej poezji wernakularnej - temu upodobnieniu służy też wprowadzony na początku opis świtu, jak również wstęp narratora.

Podsumowując, należy zauważyć, że ta droga adaptacji wzorca romańskiego poprzez łaciński jest bardzo charakterystyczna dla naszej literatury. Wykształcenie klasyczne polskich poetów od końca XV do początków XIX wieku sprawiało, że ich adaptacja nowinek literackich zaczynała się od przefiltrowywania ich przez to, co znali ze szkoły, czyli poezję rzymską. Kochanowski, umieszczając żalącą się uciśnioną księżniczkę w wysokiej wieży nad brzegiem Wisły, tworzy niejako polską wersję rycerskiej pieśni średniowiecznej - ale materia literacka jest możliwie najbardziej klasyczna, zresztą konstytutywna dla kwereli. Kochanowski wprowadza do polszczyzny romańską chanson de malmariée poprzez klasyczną kwerelę-heroidę. Podobnie zresztą uczynił z Heroidą I Penelope Ulixi, adaptując ją w Pieśniach ksiagg dwóch I 17. Skargi Penelopy na długą nieobecność Odysa znów poprzedza wstępem narratora, który usłyszany monolog pani sytuuje z kolei o wieczornej porze: „Słońce już padło, ciemna noc nadchodzi”. (Właściwie mamy tu połączenie chanson de malmariée $\mathrm{z}$ délaissée). Zapewne domyślał się Kochanowski związku łączącego te dwa gatunki - klasyczny i romański. Jak można przypuszczać tak dynamiczny rozwój francuskich gatunków chansons de femme dokonał się bowiem nie bez wpływu Listów

21

P. Wergiliusz Maro Eneida, przeł. i opr. Z. Kubiak, Świat Książki, Warszawa 1998, s. 329 (podaję przekład z ks. IX jako bardziej dosłowny).

Owidiusz Heroidy, przekł. i opr. W. Markowska, il. D. Leszczyńska-Kluza, Wydawnictwo Literackie, Kraków, 1986, s. 74 .

Wywodząca się bezpośrednio z Heroid Owidiusza kwerella (skarga porzuconej niewiasty) stała się już u progu średniowiecza osobnym gatunkiem literackim. Przyjmowała tu często postać tzw. heroidy chrześcijańskiej (listy świętych niewiast) czy skargi upersonifikowanych miast pokonanych i zdobytych przez wrogów (skarga adresowana była do władców, którzy mogli przyjść im z pomocą). M. Cytowska Kwerela i Heroida alegoryczna, "Meander" 1963 z. 11-12, s. 486-503. 
heroin Owidiusza, cieszących się tam w XII wieku powodzeniem dorównującym jedynie jego Metamorfozom. Heroidy weszły do literatury Franków u samych jej początków - pierwszej bowiem adaptacji i alegoryzacji Heroid dokonał Wenancjusz Fortunatus w VI wieku²4.

\section{Chanson de délaissée}

\section{Adam Władysławiusz}

Do opisu zorzy z Pieśni VIII z Fragmentów nawiązywało wielu późniejszych poetów. Wspomnieć tu trzeba zwłaszcza o długiej pieśni Adama Władysławiusza Rozmowa młodzieńca $z$ Panna, który od niej precz odjeżdża (1607). To tekst $\mathrm{z}$ gatunku chanson de délaissée, tyle że włożony w ramy narracji poety-obserwatora. Zwabiony urokiem porannej zorzy wychodzi on na zewnątrz i staje się mimowolnym świadkiem rozstania dwojga kochanków o świcie. Ich dialog przeradza się w żale dziewczyny, którą niefrasobliwy młodzian, mamiąc miłością, uwiódł, wykorzystał i porzucił o świcie.

Rano, gdy jasna zapala się zorza,

Słońce wypada z głębokiego morza,

Wynidę trochę, przechadzam się mało

Po pięknej rosie, a w tym mi się zdało

Usłyszeć on głos dziwnie żałobliwy,

Na poły z płaczem i bardzo rzewliwy,

Jednej panienki na nieszczęście swoje,

Które z nią zaszło prawie w krwawe boje $e^{25}$. (1-8)

Wiele podobnych utworów, zwłaszcza portugalskich cantigas de amigo, rozpoczyna się właśnie opisem świtu (te zwykle jednak były dużo bardziej ascetyczne).

\section{Rozstanie o świcie \\ 1. Alba de séparation}

24 A.M. Wasyl An aggrieved heroine in Merovingian Gaul. Venantius Fortunatus, Radegund's lament on the destruction of Thuringia, and echoing Ovid's Heroides, "Bollettino di Studi Latini" 2015 $\mathrm{XLV} / 1$, s. 64-75. 


\section{Jan Smolik}

Jak wspomniano wyżej, najbardziej reprezentatywnym gatunkiem liryki miłosnej osnutej wokół opisu wschodu jutrzenki jest prowansalska alba. Koncentruje się wokół obrazu świtu (każdą strofę kończy słowo alba, oznaczające zorzę poranną), który przynosi rozstanie kochanków, wywołując w nich oraz w czuwającym nad nimi strażniku różnorodne, często gwałtowne emocje: rozpacz, strach, gniew, żal, niedowierzanie. Towarzyszą temu wyznania miłości i przywiązania do obiektu uczuć bądź - w przypadku strażnika - ochranianych przyjaciół, nierzadko też niechęci czy wstrętu wobec zazdrośników i szpiegów czy zdradzanego męża. Ekspresji dodaje też częsta tu forma dialogu strażnika z jednym z kochanków. Jak dowodzą najnowsze badania - wbrew dawnym teoriom o pochodzeniu alby od rycerskiej pieśni wartowniczej - jest ona dworną wersją chanson de malmariée ${ }^{\mathbf{2 6}}$.

$\mathrm{Z}$ polskiego repertuaru najbliższa albie (w jej podstawowej formie: alba de séparation - alba rozstania) jest wiersz Jana Smolika (156o-1599/1605) Do Jadwigi $R$. Ponieważ utwór ten stanowi ciekawy przypadek genologiczny, zatrzymajmy się chwilę przy jego budowie formalnej. Składa się on z czternastu trzynastozgłoskowców i dzieli na wyraźne cząstki tematyczne, które należałoby graficznie podzielić na cztery strofy: trzy tetrastychy, po których następuje volta i puentujaccy całość kuplet. I choć mamy tu proste rymy parzyste, męskie, niekiedy gramatyczne - typowe dla ówczesnej poezji polskiej, to wydaje się, jakby poeta próbował zmierzyć się z sonetem - nie uwzględniając rymów. Pamiętać jednak należy, że najwcześniejsze trzy sonety polskie pochodzą od starszego o pokolenie od Smolika Jana Kochanowskiego (Fraszki I 97, II 105, III 24, ed. 1584). Pełny rozwój sonetu polskiego przynoszą natomiast tworzone w tym samym mniej więcej czasie co utwory Smolika Rytmy albo wiersze polskie (ed. 16oo) zmarłego w 1581 roku Mikołaja Sępa Szarzyńskiego oraz Setnik rymów duchownych (ed. 1590) Sebastiana Grabowieckiego. Czy, pisząc swój wiersz, mógł znać tamte? Niektóre z nich krążyły w obiegu rękopiśmiennym, zaś wiersza Smolika nie potrafimy datować - jego utwory

Ch. Chaguinian Introduction. L'alba occitane: un corpus composite, w: Les albas occitanes, étude, et édition par Ch. Chaguinian, transcription musicale et étude des mélodies par J. Haines, Champion, Paris 2008, s. 23-70; tegoż A'alba dans le système des generes troubadouresque. Réflexions sur le rapport des troubadours à la production non troubadouresque, "Cahiers de Civilization Médiévale" 2007 No. 198, s. 131-147. Szerzej na ten temat piszę w: Romańskie gatunki porannych i wieczornych pieśni miłosnych (alba/aube, alborada/aubade, mattinata, serena, serenada), "Terminus" $2019 \mathrm{nr} 2$ (w przygotowaniu). Artykułowi towarzyszyć będzie edycja tekstów w przekładzie Magdaleny Pabisiak. 
zachowały się w dwóch rękopisach powstałych już po śmierci autora (1613 i lata 20. XVII wieku). Z pewnością czytał Kochanowskiego, lecz niekoniecznie musiał dostrzec we fraszkach znane mu z literatury włoskiej sonety. Byłażby to próba stworzenia sonetu na własną rękę - i miarę poetycką? Bardziej prawdopodobne, że wiersz ten jest przekładem jakiegoś włoskiego sonetu - stąd charakterystyczne rozmieszczenie treści w obrębie strof. Odtworzenie wzorca metrycznego sonetu przekroczyło jednak możliwości autora.

Choć Smolik talentem nie dostawał najlepszym swoim współczesnym, ten wiersz odznacza się wyjątkową urodą i liryzmem:

Już Tytan wóz zaprząga świtorannej Zorze,

A śle nowym Japonom czarną Noc za morze;

Już Febus warkocz złotych rozpuszcza promieni,

Niebo się na pogodę w śliczne barwy mieni.

Lecz żeś ode mnie poszła, a żem sam bez ciebie,

Znowu się u mnie zmierzcha, znowu Noc po niebie

Kruki swoje pogania, gwiazdy się szykują,

A zorze złotobarwe nazad ustępują.

Jeśli tedy chcesz, żeby swym porządkiem rzeczy

Szły, drugi raz tak pilno nie miej na swej pieczy,

Co się dzieje na dworze, bądź że hejnał grają,

Bądź że się po ulicy ludzie przechadzają.

Poleż dłużej, nie kwap się, a chociaż dzień wszędzie,

Nic to, okna zamknąwszy, u nas wnet noc będzie. ${ }^{27}$

Pierwszy tetrastych przynosi obraz wschodzącego świtu i zorzy porannej odmalowanej terminami klasycznymi. Z nim skontrastowana została druga strofa, przy czym wersy układają się paralelnie: zapowiedzianemu zaprzęganiem wozu tytana Heliosa pojawieniu się Zorzy-Aurory odpowiada odejście ukochanej spłoszonej świtem. I oto osamotniony kochanek pogrąża się w ciemności, odesłana aż do Japonii bogini Noc-Nyx powraca, zamiast

27 Wiersz przytaczam za edycją J. Smolik Utwory zebrane, opr. R. Grześkowiak, Sub Lupa, Warszawa 2018, (Epigramaty IV 94), s. 289, dodając jednak układ stroficzny (z tego powodu przytaczam go in extenso) i zmieniając nieco przestankowanie. 
złotego warkocza promieni Feba-Słońca nadciągają czarne kruki Nocy. Porządek natury został odwrócony i tylko powrót dziewczyny może go przywrócić. Dlatego trzecią strofę wypełnia żałosna prośba kochanka, by następnym razem nie zważała na świt za oknem, hejnał poranny i ludzi, którzy już wyszli na ulicę i pewnie mogą ją dostrzec u kochanka. Całość puentuje dystych, dający rozwiązanie paradoksu i pełen prostoty sposób przywrócenia porządku natury: gdy zostaniesz, zamkniemy okna i znowu zrobi się noc.

Ten quasi-sonet utrzymany w stylistyce petrarkistowskiej zapowiada już lirykę barokową. Zawiera też podstawowe cechy alby: świt gwałtownie przerywający tajemne spotkanie kochanków, zmuszający - co ciekawe i rzadkie kobietę do opuszczenia domu mężczyzny. Odwrócone (zwłaszcza względem literatury chrześcijańskiej wiążącej świt z odrodzeniem, zmartwychwstaniem i nadzieją) wartościowanie dnia i nocy - to noc sprzyja kochankom i jest przez nich pożądana i wyczekiwana, zaś dzień nadchodzący w urzekającej szacie zorzy porannej witany jest z niechęcią, żalem, trwogą czy wręcz przeklinany.

W literaturze polskiej tego czasu jest to odosobniony przypadek - najbardziej „klasyczna”, literacka alba, sytuacja liryczna dalece odbiega od współczesnej obyczajowości. Na jakich tekstach i w jakich językach powstałych mógł się wzorować Smolik? Trudno dziś powiedzieć. Biografia poety (znana szczątkowo) i inne utwory wskazywałyby na poezję włoską.

\section{Chanson de départie}

\section{Szymon Zimorowic}

Opisu rozstania o świcie dostarcza również pieśń Szymona Zimorowica (1608-1629) drukowana najpierw pod tytułem-imieniem Janella (III 4) w jego zbiorze Roksolanki to jest Ruskie panny (1654), a następnie anonimowo jako Taniec X w nieco zmienionej wersji w antologii Koło tańca wesołego (1564).

Napisany na ślub brata cykl Roksolanek, choć kunsztownie skomponowany ${ }^{28}$, potraktować można również jako swoistą antologię europejskiej liryki erotycznej.Prezentując bowiem rozmaite odmiany miłości i losy kochanków, Zimorowic odwołuje się do wielorakich form, tematów i wzorców gatunkowych znanych z poezji europejskiej. Nie są one jeszcze wyczerpująco opisane, a wzorce zidentyfikowane, a warto by się pokusić o takie rozpoznanie tradycji

Zob. P. Stępień Cykl jako droga do nieśmiertelności. O „Roksolankach”Szymona Zimorowica, w: Od Kochanowskiego do Mickiewicza. Szkice o polskim cyklu poetyckim, red. B. Kuczera-Chachulska, Wydawnictwo IBL PAN, Warszawa 2004. 
fundujących ten cykl. Janella doskonale wpisuje się w typ chanson de départie (można też użyć tu bardziej zadomowionego terminu waleta).

Jest to pieśń dziewczyny relacjonującej swoje pożegnanie z wyjeżdżającym na dłużej młodzieńcem. Przybywa on o zmierzchu, wyjazd ma nastąpić o bladym świcie, panna stara się go zatrzymać jak najdłużej. Kolejne siedem strof rozpoczyna precyzujący porę opis nieba i ciał niebieskich - „Słońce jasność swą straciło, noc powstaje"29 (w. 1); „Już nastąpił czas wieczorny, Hesper wschodzi” (5); „Już roztoczył księżyc promień swój różany” (9); „Już blisko jest o północy słyszeć dzwony" (13 - tu jedynie odmiana w sposobie określania godziny); „Jutrzenka już jasna weszła” (17); „Już rumiane do połowy zbladły zorze” (21); „Dzień biały świat już ogarnął, noc rozegnał” (25). Drugie wersety strof pokazują etapy pożegnania - działania chłopca, który „się rozstaje”, „odchodzi”, „opuszcza”, „rękę daje”, , spieszy w daleką dziedzinę”, „wyszedł na podwórze”, „mnie pożegnał”, przy czym w każdej strofie określony jest on emocjonalnym epitetem oddającym jej przywiązanie i miłość. Tym czynnościom odpowiadają zawarte w dwóch końcowych wersach tetrastychów powstrzymujące go słowa dziewczyny: „pohamuj swej drogi”, ,zostań na godzinę”, „potrwaj, proszę, mało”, „poczekaj na chwilę”, „postój”. Zatrzymany w ten sposób przez całą noc młodzieniec odjeżdża o świcie żegnany życzeniami szczęścia zakończonymi prośbą o pamięć oraz subtelną przestrogą wskazującą upływ czasu i młodości.

Zimorowic wzoruje się na wersji nowożytnej gatunku - nie mamy tu dziewczyny żegnającej kochanka, lecz mocno zakochaną choć nienachalną pannę, która ma nadzieję na ustabilizowanie trwałego związku: „jednak ty statecznie kochaj we mnie wiecznie. / Jeśli zechcesz, jam twoją koniecznie." (43-45).

Pominąwszy w tym zestawieniu utwory hejnałowe Hieronima i Zbigniewa Morsztynów, o których piszę osobno, spójrzmy na dwa wiersze ich młodszego krewniaka, Jana Andrzeja Morsztyna (1621-1693): Na sen (ze zbioru Pieśni, 5) oraz Do Zorze (Lutnia, 173). Domyślić się można w nich inspiracji cyklem wierszy Al Sonno Giambattisty Marina, w których sen, jego złuda i rozkosze, ukojenie i zdradliwa bliskość śmierci stanowią temat refleksji filozoficznej i egzystencjalnej (por. Rime amorose 61-63, 71). Związek wierszy Morsztyna z nimi jest jednak dość luźny, w polskich lirykach można natomiast rozpoznać dwa warianty alby, które wydawca alb prowansalskich, Christophe

29 Sz. Zimorowic Roksolanki to jest Ruskie panny, wydał R. Grześkowiak, Wydawnictwo IBL PAN, Warszawa 1999, s. 96-97. 
Chaguinian określa jako alba de séparation (świt zmusza kochanków do rozstania, zwiastująca go zorza jest im wroga i witana z żalem i obawą) oraz alba formelle érotique $e^{30}$ (samotny kochanek i zarazem poeta, w czasie bezsennej nocy spędzonej na rozpamiętywaniu i tęsknocie, przyzywa świtu).

\section{Alba de séparation - wariant żałobny}

\section{Jan Andrzej Morsztyn}

Piękny, subtelny liryk Na sen to lament kochanka, którego nocne spotkanie z dziewczyną zostaje zniweczone przez wzejście słońca. Ono też jest tu obciążone winą za odebranie jedynej pociechy i pogrążenie bohatera na powrót w mroku żałoby.

Słońce zazdrościwe,

Czemu mię budzisz

I żałościwe

Myśli krótką pociechą łudzisz?

Ranne twe wstanie

Smaczne mi rwie spanie ${ }^{31} \cdot(5-10)$

Spotkanie bowiem dokonało się we śnie, bo tylko rojąc sny, osierocony mężczyzna mógł cieszyć się wizerunkiem zmarłej ukochanej. Człowiek jest tu w mocy trzech walczących ze sobą bóstw: Śmierci, która mu odebrała Zosię, Snu, który mu ją przywraca i Słońca, które odarło go ze złudzen'32. Przy czym Słońce jest nie tylko winne zniweczenia pocieszającej ułudy sennej, ale - analogicznie do innych liryków Morsztyna ten temat eksploatujących ${ }^{33}$ ono było też jej dawcą, wytwórcą znikomego obrazu - ułudy, cienia, który

Les albas occitanes..., s. 58-63. Przykładem takiej pieśni jest Uc'a de Bacalaria, Per grazir la bon' estrena, zamieszczona w zapowiadanej edycji.

31 Tekst przytaczam za poprawioną redakcją L. Kukulskiego w tomie J.A. Morsztyn 275 wierszy, oprac. L. Kukulski, PIW, Warszawa 1977, s. 124-125.

32 Morsztyn polonizuje mit o braciach Hypnosie i Tanatosie, dostosowując ich płeć do formy gramatycznej, mamy więc brata Sen z siostrą Śmiercią. "Sen z śmiercią, brat z siostrą: / Wiodą zwadę ostrą: / Ta wegnała Zosię w ciemne kraje, / [A] ten mi ją na noc w myśli daje" (1-4).

G. Urban-Godziek Petrarkistowskie źródła sennej erotyki Jana Andrzeja Morsztyna, w: Amor vincit omnia. Erotyzm w literaturze staropolskiej, red. R. Krzywy, Semper, Warszawa 2008, S. 118-133. 
występuje tu na równi z innymi barokowymi ikonami złudy, pozoru, fałszu: snem i dymem.

Lecz konterfekt, który-m miał za żywy,

Nie był, tylko dym i cień prawdziwy.

Krótko tej pociechy,

I widzę prawie,

Że me uciechy

Przez sen tylko są, a na jawie

Za weściem słońca

Nie masz bólu końca. (13-20)

Trwanie w ułudzie jest tu stanem pożądanym i prowokowanym: znikającą dziewczynę prosi, by albo zabrała go ze sobą (zgodnie z konwencją epicedialna), albo przynajmniej zjawiła się jeszcze raz: „zawieram oczy / czekać ochoczy” (30).

Można się tu domyślić inspiracji wspomnianym sonetem 62 Al Sonno Marina, w którego ostatniej strofie wyraźne jest odwołanie do gatunku alby. Sonet Marina to skarga na Noc, która nie przynosi ukojenia, i Sen, który tylko łudzi nieszczęsnego przywidzeniami. Dlatego, gdy duch zmarłej chce go objąć, Marino - jak strażnik z alby - ostrzega ją, by uciekała z powrotem do otchłani, bo zaraz nadejdzie groźny dla niej świt - alba:

Fuggi agli abissi omai, già ti minaccia

l'alba, e 'l sol che ritorna. Ecco il pensiero,

il nemico pensier, che ti discaccia. (Al Sonno, 12-14).

[Umykaj już do otchłani, bo grozi ci zorza i powracające słońce. Oto myśl, nieprzyjazna myśl, która cię odpędza.]

Byłby to więc wariant podstawowy alby (alba de séparation), ale w wersji żałobnej, gdzie spotkanie miłosne kochanków może dokonać się jedynie we śnie $^{34}$. O dworskiej (pochodzącej z chanson trobarique) proweniencji formy gatunkowej wiersza świadczy również to, że monolog liryczny włożony jest w usta mężczyzny.

34 Na temat takich spotkań zob. G. Urban-Godziek De consolatione somni - figura Pocieszycielki w renesansowej poezji miłosnej. Jan Kochanowski w nurcie łacińskiej literatury europejskiej (Boecjusz, F. Petrarca, G. Pontano, I. Secundus), "Terminus" 2014 Z. 1, s. 93-121. 


\section{Alba formelle érotique}

\section{Jan Andrzej Morsztyn}

Sonet Do Zorze (Lutnia 173) zachował się w dwóch rękopiśmiennych wersjach, w których pierwsze dwie strofy są nieco odmienne i realizują inny wariant metryczny ${ }^{35}$. Przejęty „troską miłosną” bohater nie potrafi zaznać ukojenia ani w danej człowiekowi dla wytchnienia nocy, ani w jasności dnia. Nawet uroda wschodzącej zorzy nie przynosi mu ulgi. Jedynie przyniesiona przez nią poranna rosa mogłaby wspomóc go - w płaczu. To echo mitu aitiologicznego wiążącego zjawisko rosy porannej z żalem Eos, która wschodząc na niebo, opłakuje poległego pod Troją syna Memnona. Jednak w trzeciej strofie Morsztyn explicite odwołuje się do innego mitu, Eos zakochanej w Kefalosie ${ }^{36}$. (Biorąc pod uwagę omawiany wyżej wiersz, odwołania do tych dwóch mitów mogą być celowe, a samotność kochanka spowodowana śmiercią ukochanej). Powołując się więc na ich wspólnotę uczuć, udręczony bólem niespełnienia i bezsennością prosi rozżarzoną rudą poświatą boginię, by ustąpiła już świtowi, tak samo blademu jak on (bladość jako znamię cierpień miłosnych):

Zorzo, chcesz-li mi pomóc żalu wiernie,

Zbądź tej różanej swojej rumianości,

A oblecz bladą farbę mego ciała. (12-14).

Taką postać wiersza i wykorzystanie motywu zorzy wydaje się konceptystyczną wariacją na temat - zwanego przez niektórych badaczy kontr-albą - jej podgatunku alba formelle érotique. Tam podmiotem jest mężczyzna spędzający w smutku i tęsknocie samotną noc. Nie mogąc spać, przyzywa świt.

\section{Podsumowanie}

Polska poezja XVI i XVII wieku wciąż jest stosunkowo słabo opracowana. Przedstawione studium miało na celu zaproponować nowe sposoby

35 J.A. Morsztyn Utwory zebrane, opr. L. Kukulski, PIW, Warszawa 1971, s. 107 i 817.

A. Nowicka-Jeżowa J.A. Morsztyn i G. Marino. Dialog poetów europejskiego baroku, Wydawnictwa UW-Wydział Polonityki UW, Warszawa 2000, s. 275, wskazuje na odwołanie do Scherzo maritimo, Canti Amorosi 107 Marina (mit Cefala). Sugeruje również związek wiersza Do Zorze z sonetem Era del mio bel Sol chiaro lucente (Rime Am.71), trudno jednak odnaleźć bliższe powinowactwo między tymi utworami. 
klasyfikacji i opisu liryki miłosnej. Ta część literatury bowiem, łącznie z utworami uważanymi ongiś za pochodzenia ludowego, wyraźnie wykazuje cechy gatunków wykształconych w średniowiecznej poezji romańskiej, a cieszących się niesłabnącą popularnością w nowożytności. Analizie poddano utwory, które koncentrują się wokół opisu zorzy porannej, a przez to oscylują wokół gatunków pokrewnych najbardziej tu reprezentatywnej albie prowansalskiej. Większość rozważanych przykładów jeszcze lepiej niż alba charakteryzuje jednak archaiczny typ chansons de femme, którego rozliczne warianty były najwyraźniej dobrze znane polskim autorom. Kwestią otwartą, wymagającą dalszych badań, pozostaje droga, jaką dotarły one do Polski. Najbardziej prawdopodobne jest pośrednictwo madrygałowych pieśni włoskich, popularyzowanych w całej Europie, w tym w Rzeczypospolitej, przez wędrownych muzyków włoskich.

\section{Abstract}

\section{Grażyna Urban-Godziek}

JAGIELLONIAN UNIVERSITY (CRACOW)

Polish Sixteenth-and Seventeenth-Century Morning Love Songs and the Sub-Genres of Chansons de Femme

Grażyna Urban-Godziek proposes a new genre classification based on the work of French medievalists to be applied to Polish love poetry from the sixteenth and seventeenth centuries. The theoretical introduction presents thematic variants of a basic genre of popular Romance lyric poetry, namely the chanson de femme (a woman's mournful love song). Urban-Godziek then examines a series of old-Polish works linked by descriptions of dawn (typical of the Old Occitan alba being a trobarique version of the chanson de malmariée); what is more, each one of them seems to be a variant of the chanson d'ami: chanson de délaissée and chanson de départie or chanson de malmariée. Examples of alba de séparation and alba formelle érotique are also presented.

\section{Keywords}

old-Polish poetry, chanson de femme, Jan Kochanowski, Jan Smolik, Szymon Zimorowic, Jan Andrzej Morsztyn, Adam Władysławiusz 